\title{
THE COUNCIL ON FOREIGN RELATIONS
}

The Council on Foreign Relations (CFR) is an independent, nonpartisan membership organization, think tank, and publisher dedicated to being a resource for its members, government officials, business executives, journalists, educators and students, civic and religious leaders, and other interested citizens in order to help them better understand the world and the foreign policy choices facing the United States and other countries. Founded in I92I, CFR carries out its mission by maintaining a diverse membership, with special programs to promote interest and develop expertise in the next generation of foreign policy leaders; convening meetings at its headquarters in New York and in Washington, DC, and other cities where senior government officials, members of Congress, global leaders, and prominent thinkers come together with CFR members to discuss and debate major international issues; supporting a Studies Program that fosters independent research, enabling CFR scholars to produce articles, reports, and books and hold roundtables that analyze foreign policy issues and make concrete policy recommendations; publishing Foreign Affairs, the preeminent journal on international affairs and U.S. foreign policy; sponsoring Independent Task Forces that produce reports with both findings and policy prescriptions on the most important foreign policy topics; and providing up-to-date information and analysis about world events and American foreign policy on its website, www.cfr.org.

The Council on Foreign Relations takes no institutional position on policy issues and has no affiliation with the U.S. government. All statements of fact and expressions of opinion contained in its publications are the sole responsibility of the author or authors. 
This page intentionally left blank 
I dedicate this book to my parents and all those who suffered at the hands of the revolution. 
This page intentionally left blank 